Article

\title{
Energy-Efficient Building Design for a Tropical Climate: A Field Study on the Caribbean Island Curaçao
}

\author{
Richenel Bulbaai ${ }^{1}$ and Johannes I. M. Halman ${ }^{2, *}$ \\ 1 Faculty of Engineering, University of Curaçao, Jan Noorduynweg 111, Willemstad, Curacao; \\ richenel.bulbaai@uoc.cw \\ 2 Department of Construction Management \& Engineering, Faculty of Engineering Technology, \\ University of Twente, P.O. Box 217, 7500 AE Enschede, The Netherlands \\ * Correspondence: j.i.m.halman@utwente.nl
}

check for updates

Citation: Bulbaai, R.; Halman, J.I.M. Energy-Efficient Building Design for a Tropical Climate: A Field Study on the Caribbean Island Curaçao. Sustainability 2021, 13, 13274. https:/ / doi.org/10.3390/su132313274

Academic Editors: Antonio Caggiano and Deepankar Kumar Ashish

Received: 30 June 2021

Accepted: 22 November 2021

Published: 30 November 2021

Publisher's Note: MDPI stays neutral with regard to jurisdictional claims in published maps and institutional affiliations.

Copyright: (C) 2021 by the authors Licensee MDPI, Basel, Switzerland. This article is an open access article distributed under the terms and conditions of the Creative Commons Attribution (CC BY) license (https:// creativecommons.org/licenses/by/ $4.0 /)$.

\begin{abstract}
Based on an extensive literature review on passive building designs for tropical climates, seven energy-efficient building design principles for tropical climate areas were deduced. These are: 1. To orientate a building design in such a direction that it protects from excessive solar radiation; 2. To accommodate for indoor natural ventilation; 3 . That it makes maximal use of indirect instead of direct natural light; 4 , That it reduces the amount of heat transmission through the roof as much as possible by natural ventilation between roof and ceiling and by lowering the roof surface temperature; 5. By preventing the use of high thermal mass materials; 6 . By reducing through the exterior walls as much as possible heat transmission by e.g., preventing direct sunlight on the external walls and applying reflective paints on the external walls and; 7 . By creating outdoor and transition spaces such as balconies, terraces atriums and corridors. The insights from the literature review were used as input to conduct a field study to evaluate the practice of applying passive building design principles. To this end, for 626 buildings on the Caribbean island Curaçao, it was investigated to what extent the recommended passive design principles for tropical climates were actually applied. Based on the results of the field study, several recommendations are made to improve the practice of applying passive building principles.
\end{abstract}

Keywords: passive design principles; building design for tropical climates; sustainable energy use; energy efficiency; application of passive building design principles in Curaçao

\section{Introduction}

Energy use in buildings in tropical climates is of great concern because many electromechanical systems are used to moderate the high humidity and high temperatures [1], and also the artificial lights used for indoor illumination. To date, sustainable architecture for hot climate areas remains a relatively unexplored area [2]. 'Passive design' is a design that takes advantage of the climate and natural energy resources, such as daylight, wind and thermal buoyancy, to achieve a comfortable environment while minimizing energy use and reliance on mechanical systems [3].

Passive design strategies can improve buildings' indoor comfort, enhance energy efficiency in buildings, and minimize buildings' energy use [4]. Moreover, the design and construction of buildings can affect the environment, both directly and indirectly [2]:

1. Directly, by constructing buildings and their infrastructure on green areas;

2. Indirectly, through the extraction of resources to make building materials, the transportation of these materials, energy use once the building is functioning, and greenhouse emissions as a consequence of these activities.

Buildings in tropical areas were traditionally designed and constructed to take advantage of the sun and the wind [5]. However, in recent decades, in many cases, less attention has been given to aspects related to the sun and the wind in a building's design. 
For instance, Tantasavasdi, Srebric, and Chen [6] found that, in the past few years, passive cooling design elements have been missing from building designs. The natural indoor temperature consequently increases, and extra air conditioners or other electro-mechanical systems are then installed. According to Kitio, Butera, Adhikari, and Aste [7], the current building process consists of three steps: architectural design, design of electro-mechanical systems, and construction. Passive design is absent from this process. "Passive design in the tropics means designing a building to make the most of natural light and cooling breezes, and using shading, orientation, and appropriate building materials to reduce heat gain and storage" [2]. A good passive design results in an energy-efficient and comfortable building. As a consequence, the capacity of mechanical ventilation systems can be reduced, mainly due to the reduction in a building's peak temperature during the day [8].

An important aim of this study was to develop a comprehensive overview of passive design principles that can be used in the design and construction of buildings in tropical areas. Next, the identified passive design principles are used as a reference to evaluate the state of passive design and construction of buildings on the Caribbean island Curaçao. To this end, 626 buildings on Curaçao were evaluated on their application of passive design principles.

The rest of this paper is organized as follows. Section 2 provides a literature review of the key tropical building design principles that can be applied for obtaining passive design results in tropical areas. Section 3 explains the research steps that were taken to conduct the field study in Curaçao. Section 4 presents the results of the field study of the application of passive design principles in Curaçao. And in Section 5, the findings of the field study are mirrored against the passive building design principles as recommended in literature. This paper ends with a discussion on the scientific contributions and practical implications of the paper and provides recommendations for further research.

\section{Key Tropical Building Design Principles: A Literature Review}

The following paragraphs describe the most important design rules that should be taken into account in the design and construction process of a tropical building to improve thermal comfort and reduce energy use.

\subsection{Building Orientation}

Excessive solar radiation causes a building's indoor temperature to rise as a consequence of the solar heat infiltration. Therefore, the orientation of a building in the tropics is crucial [8] because it can influence access to natural light, protection from excessive solar radiation, and the extent of the prevailing winds on the façades of the building. The prevailing winds have two functions, namely, to facilitate ventilation in a building as well as to ventilate the façades of the building [9]. Kitio et al. [7] stated that the parts of a building where thermal comfort is an important requirement, such as a bedroom, should be situated to the side with the most wind. This is because the effect of mass-stored solar radiation in a building is still noticeable in the late evening. Conversely, other spaces such as restrooms and storage rooms can be located on the side with least wind. Moreover, Kitio et al. [7] advised that most windows and the longest walls of a building should be out of direct sunlight. Nevertheless, the input of natural light and the maximum prevailing winds should be permitted.

\subsection{Natural Ventilation}

Ventilation is the process of removing stale air and replacing it with fresh air, either through mechanical systems or by natural methods [10]. When no mechanical systems are used in this process, it is referred to as natural ventilation or passive ventilation. Natural ventilation is important because it is an effective passive cooling design technique that reduces the need for energy to power mechanical ventilation systems $[6,11]$. Two advantages of natural ventilation are that it reduces the energy use of the buildings and increases the thermal comfort in the building [12]. Furthermore, natural ventilation is 
recommended as a way to encourage cross ventilation in buildings in the tropics. Effective cross ventilation in a building can be provided by placing windows in opposite walls. To encourage cross-ventilation in the bedrooms, while maintaining privacy for the occupants, louver doors, or louvered windows above the doors, can be installed. The type and location of the windows, the balcony configuration and the internal layout determine the patterns of the indoor air flows and can improve the indoor comfort level [13].

Limiting obstacles to airflow in a building is also recommended [2,14]. In addition, to stimulate mixing between fresh air and the air already in a building and to maximize airflow, the windows should not be directly in line [7,12]. Furthermore, Brown et al. [5] recommended that the height of ventilation openings in dwellings should be at the occupant's upper body level, and that the building's interior walls should be thin and not hinder the airflow. Convective air movement or stack ventilation, which is based on temperature differences, can also improve cross-ventilation. Low-level inlets and high-level outlets located on opposite sides of a building produce a "stack effect" [15].

Openings on the upper level of the building let the warm air inside the building escape, while the cooler fresh air infiltrates through openings at a lower level in the building. Basically, this stack effect induces cool fresh air infiltration through openings at a lower level of the building and warm air removal through higher openings in the building [14].

The study by Tantasavasdi et al. [6] showed that using larger inlets than outlets and keeping the interior space as open as possible so that the wind can circulate freely, keeping the long rooms windward, and using ceiling fans can increase the velocity of the room air.

The solar chimney is another design to encourage convective air movement. This technique consists of a tall vertical chamber. During the day, the air inside this chamber is heated by solar radiation. This increases the difference in temperature between the incoming and out coming air. The natural convection therefore increases and this boosts the air circulation through the building. Experimental observations have shown that solar chimneys have the ability to reduce the heat gain of the building and ensure thermal comfort. The velocity of air can be increased by using more solar chimneys or by increasing the surface area of the solar chimneys. Solar chimneys seem more efficient than opening windows and doors [16].

Another natural ventilation technique is to raise the building off the ground. This encourages fresh air supply from underneath, which cools the floor [2,5]. Another ventilation technique which is often used in the tropics is the use of ventilation blocks to enhance ventilation. Ventilation blocks are often used for ventilation purposes in buildings in Curaçao.

Kitio et al. [7] argued that today, buildings should be designed to be integrated with the open air. This integration can provide a comfortable and healthy indoor environment, with a minimum use of energy for lighting, cooling, and ventilation. It is important to note that natural ventilation cannot entirely replace air conditioning units in hot climates. Consequently, Kitio et al. [7] proposed dividing buildings into different areas-those where only natural ventilation would be used and air-conditioned zones that needed additional air conditioning. Tantasavasdi et al. [6] suggested several measures to increase natural ventilation, especially for houses. The most important of these are as follows:

- $\quad$ creating larger openings to serve as inlets and outlets;

- $\quad$ enabling free wind passage in buildings, by avoiding hindrances to the airflow; and

- designing buildings with more than one floor-the upper floors will receive better ventilation, and the ground floor can serve as a parking space and/or service area.

Mallick [9] also argued that buildings with upper floors encourage natural ventilation. Even if a building is designed with natural ventilation possibilities, ventilation can be drastically impeded, for instance by security grills and insect netting. The use of ceiling fans can also increase the airflow in the buildings [17]. 


\subsection{Indirect Natural Light}

The use of indirect natural light in buildings to illuminate their interior is crucial in any climate conditions. It reduces the energy use from artificial lighting as well as the interior thermal gains from this lighting. The orientation, shape, and surface openings of a building determine the extent of natural light [9]. Apart from windows and doors, indirect natural light can be acquired through skylights, light reflectors, and similar installations such as atria. Skylights and atria can provide plenty of light to a building's interior; however, they must be shaded or glazed in warm climates to restrict unwanted heat penetration. Other advantages of skylights and atria are that some of these installations have an opening at the top to allow hot air to escape [2].

Windows provide indirect natural light and direct airflow into most buildings. The size, material, and position of windows should be determined by the location and the façade orientations [9]. It is important, especially in the tropics, that the windows be both exposed to and shaded from direct sunlight. There are several measures that can be used to minimize the heat input through windows such as tinted glass, other glazing technologies, overhangs, louvers, and reflective coatings [2].

\subsection{Roof Ventilation}

The roof is the part of a building that receives the most solar radiation. The roof absorbs the heat from the sun and transmits it to the interior of the building. There are several ways to minimize the solar incidence on the roof, such as the following:

1. Encourage natural ventilation of the space between the roof (insulated with down facing Reflective Foil Insulation) and ceiling insulation. Roof space ventilation reduces heat storage and minimizes the heat flow to the interior of a building. Trees provide shade to cool the roof and the incoming air. Create cross-ventilation to cool incoming heat from the roof and walls [15].

2. Use materials such as zinc and aluminum as the outside layer of a roof. Metal roofs with reflective layers permit quick cooling at night. However, this material has various disadvantages including glare from dazzling sunlight and disturbances caused by the noise of wind and rain. Furthermore, the lifecycle of zinc in the tropics is often shorter than that of other materials such as fiber-reinforced roofing materials and concrete.

3. Paint the roof a light color since this will lower the surface temperature, and less heat will consequently transmit to the building's interior.

4. Slope roofs towards the prevailing wind because this will encourage roof cooling by the prevailing winds.

5. Include roof insulation as this considerably reduces the heat input to the interior of the building [5,7]. The insulation can be mounted on the upper surface of the ceiling and/or under the roofing material.

6. Employ a double-roof shading technique to reduce the heat inside a building. The external roof serves as shade for the one below and protects it from direct sunlight.

7. Add a green roof (living roof), this is a roof whose outer layer is completely or partially covered by vegetation. The vegetation acts as shading for the roof.

8. Include ventilation openings between the ceiling and the roof to stimulate the escape of hot air through these openings. The hot air leaving through these openings will be replaced by cooler fresh air.

\subsection{Thermal Mass Materials}

In building design, thermal mass is defined as a measure of a building material's ability to absorb, store, and then retransmit heat. Building materials with a high thermal mass take a long time to heat up and to cool down [10]. This means that the heat generated during high daytime temperatures is stored in a building's material and then flows out when the outside temperature drops at night [18]. Therefore, lightweight materials with a low thermal mass, such as timber, are recommended as building materials in hot climates. There are several lower thermal conductivity building materials that can provide thermal 
comfort, such as low thermal conductivity wood, cork, straw bales, vermiculite concrete, vacuum insulated panels and hollow clay tiles [19]. Moreover, when materials with a high thermal mass, such as bricks and concrete, are used, the building needs to be shaded to prevent heat gain and heat storage.

\subsection{External Walls}

The use of light colors or reflective paints for external surfaces reduces the temperature at the surface of a building and hence the building's incidental heating [8,19]. While internal insulation is another option to minimize the heat transmission to building interiors, solar shading is the most-used measure in the tropics to reduce the cooling load. For instance:

1. Simple overhangs are the most-used methods in tropical climates. Overhangs are efficient for shading buildings;

2. Vegetation on the outside of a building can also provide efficient shading for the building. However, it should not hinder natural ventilation. Moreover, planting can reduce the ground temperature and reduce the reflected heat $[1,2,19]$;

3. Spaces with thicker walls are generally more comfortable in hot and dry periods [9]; and

4. In addition to exterior shading, interior shading such as vertical louvers and venetian blinds are other options. However, the best option is to keep the heat away from the building.

\subsection{Outdoor and Transition Spaces}

The transitional or intermediate space between the inside and outside of a building can provide a shaded space for the building, and it has a cooling effect on the incoming air. There are many types of transition spaces that can be used in building design, such as balconies, terraces, atriums, and corridors.

\section{Thermal Comfort and Behavioural Adaptation}

The perception of comfort is affected by prolonged conditioning to high temperatures and humidity for people living in tropical climates. Living in a comfortable environment is necessary for human beings, especially for a healthy and productive life. Thermal comfort is related to different environmental conditions. For example, air movement, air temperature, and humidity, which in turn depend on personal variables such as clothing and activity [17]. According to Khedari et al. [16], temperature and velocity of room air are the main thermal comfort parameters. Building design can make an important contribution to indoor comfort. The variation in wall thickness can significantly affect the comfort performance of buildings.

In general, residents prefer to take measures that regulate the environment, such as opening windows, using fans and air conditioners, rather than making personal adjustments such as changing clothes and more drink to make their condition more comfortable [11]. Adaptive adaptations of the resident, such as drinking more water, changing clothes and bathing more often, also compare favorably with turning on air conditioners [20].

Cost savings, rather than environmental concerns, appear to be the most important driver of energy-saving behavior in Curaçao. In addition, the households in Curaçao are unaware of many of the available energy-efficient options that they could apply to reduce their costs and improve thermal comfort [21]. Furthermore, policies, regulations, and energy prices can influence the energy behavior of occupants.

\section{Energy Use of Air Conditioners in Curaçao}

A recent study performed by Bulbaai [21] shows that the energy use of air conditioners in the household sector in Curaçao is: $18.2 \%$ of the total energy use in in the low-income category; $26.3 \%$ in the middle-income category and; $27.5 \%$ in the high-income category. Air 
conditioners consume about $41 \%$ of total energy use in hotels, $54 \%$ in office buildings and $27 \%$ in supermarkets. However, further research is needed to estimate the energy savings potential of air conditioners in Curaçao.

Based on the literature discussed in this section, Table 1 provides a coherent summary overview of tropical building design principles, which contribute to both indoor comfort and energy savings.

Table 1. Passive building design principles for tropical climates to improve a building's indoor comfort, to enhance the energy efficiency, and to minimize energy use.

\section{A Building's orientation in the tropics is crucial:}

- $\quad$ Situate bedrooms at the side with the most wind

- $\quad$ Restrooms and storage rooms can be located at the sidewith the least wind

- $\quad$ Position the longest walls out of direct sunlight

Accommodate for natural ventilation:

- $\quad$ Place windows in opposite walls, to create cross ventilation

- $\quad$ Place ventilation openings at the occupant's upper body level

- Interior walls and obstacles should not be hindering natural airflow

- Encourage cross ventilation by using louver doors and louvered windows

- Conceive air movement through placing low level inlets and high-level outlets on opposite sides

- Apply solar chimneys to encourage convective air movement

- Raise the building off the ground

- Use open ventilation blocks

Make use of indirect instead of direct natural Light

- $\quad$ Overhangs, louvers, reflective coatings and tinted glass will reduce heat input through windows

- Apply shaded atria and skylights that also allow hot air to escape

Reduce heat transmission through the roof

- Encourage natural ventilation between roof and ceiling, e.g., through ventilation openings

- Lower the surface temperature of the roof through applying light surface colors, reflective surface layers or by covering the roof with green vegetation

- $\quad$ Slope roofs towards the prevailing wind

- Include roof insulation

- Employ a double-roof shading technique

Prevent the use of high thermal mass materials

$2.5 \quad$ - Lightweight materials with a low thermal mass are the recommended building materials in hot climates

- $\quad$ Prevent in case of the use of bricks and concrete the exposure to direct sunlight.

Reduce heat transmission through the exterior walls

- $\quad$ Apply light colors or reflective paints for external surfaces, solar shading elements and extensive vegetation outside the building

- Apply internal insulation to minimize heat transmission

Create outdoor and transition spaces windows and door and have a cooling effect on the entering air.

\section{Method of the Conducted Field Study}

The aim of the field study was to examine the extent to which passive design principles are incorporated in the design and construction of buildings on the Caribbean island Curaçao.

The Antillean island Curaçao is situated in the Southern Caribbean Sea, about $65 \mathrm{~km}$ north of the Venezuelan coast. Curaçao has a population of just over 150,000 in an area of 
$444 \mathrm{~km}^{2}$ [22]. The island extends from 68 to 70 degrees west of the Greenwich meridian and from 12 to 13 degrees north of the equator. Curaçao is located in the southern Caribbean dry zone, and it is characterized by a semi-arid to arid climate, with distinct dry and rainy seasons. The rainy season is from October until January and the dry period from February through June, with July and August referred to as the transitional months. Curaçao has was warm tropical temperatures, with the highest mean temperatures in September. The average temperature is $27.9^{\circ}$ Celsius, while the average temperature of the seawater is $27^{\circ}$ Celsius [23]. The wind blows predominantly from the east to the west throughout the year on the island. Curaçao has a relative humidity of min. $76 \%$ and max $80 \%$. The average relative humidity is $78 \%$ and the annual average vapor pressure is 28 mbar.

To gain insight into how buildings in Curaçao are designed and constructed, a field study was carried out in a large number of neighborhoods in Curaçao. These neighborhoods were Schelpwijk, Gosie weg, Tera Kòrá, Soto, Brievengat, Caracasbaai weg, Sta. Rosa weg, Saliña, Punda, Otrobanda, Ronde Klip, Cas Kòrá, Bonam, Semikok, Sta. Rosa, Montaña, Fuik, Cas Grandi, Janthiel, Brakkeput, Rooi Catootje, Soemboe, Lagun, Barber, Knip, Souax, Gato, and Westpunt. The red dots in Figure 1 indicate where the research into energy-efficient buildings was carried out. The study included 626 buildings (315 residential buildings and 311 utility buildings). The total number of buildings in Curaçao is 86,226 buildings, consisting of respectively 77,354 residential buildings and 8872 utility buildings [24]. The conducted field study focused on the orientation of the buildings, the building materials that were used, the type of windows that were used, the solar shading of walls, the type of roof material and roof paint that was used, the possible use of roof ventilation and double roof systems, and the building of transition spaces, floor levels and elevated buildings.

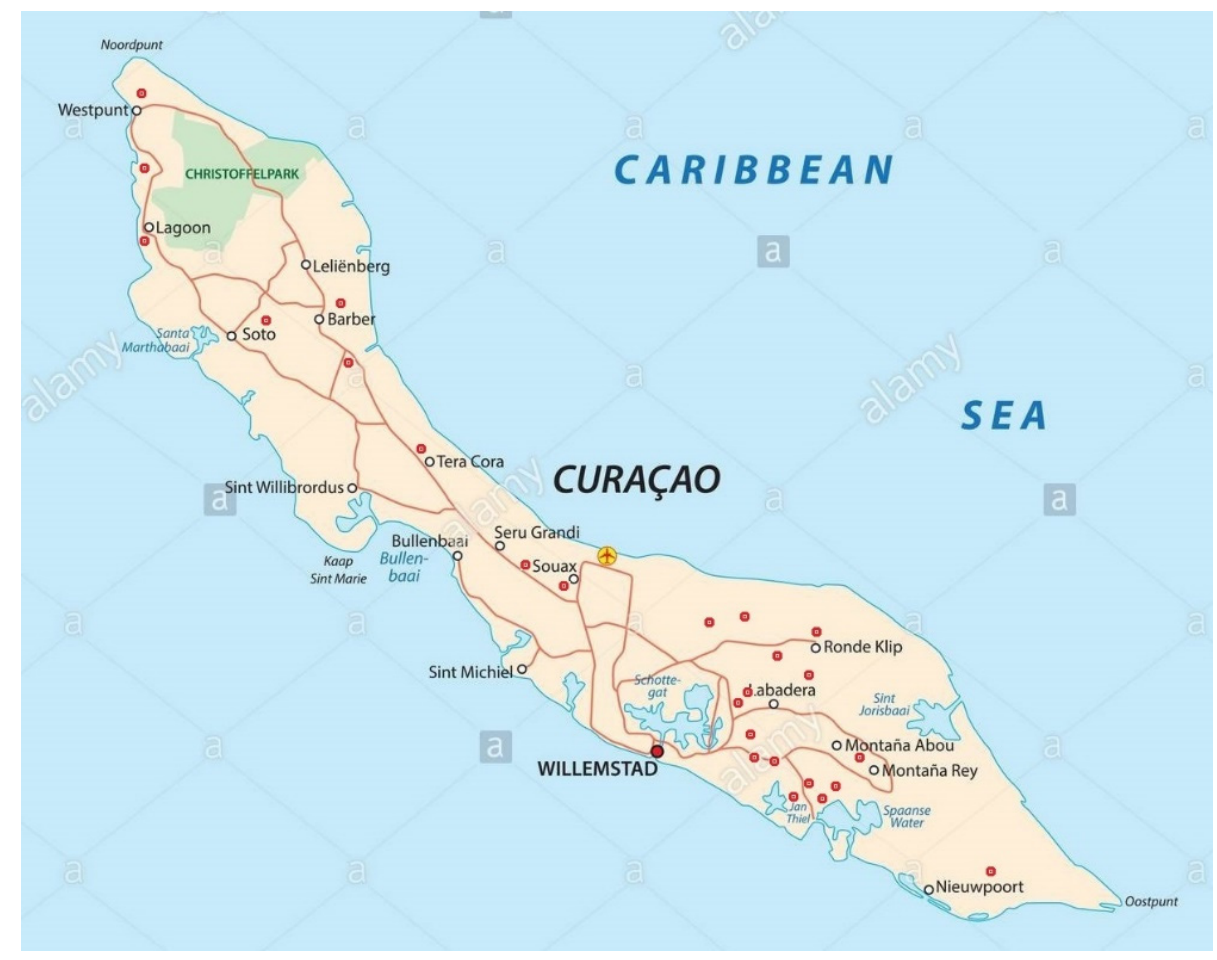

Figure 1. Curaçao map [25].

In addition to on-site visits, Google earth, Google map, and Google street view were used in this study. Google earth and Google map were used to gain insight into the colors of the roofs of the buildings and Google street view was used to get insight into the colors of the exterior façades. 


\section{Results}

The 626 buildings included in this field study were evaluated on their application of passive design principles for tropical areas. More specifically, we evaluated: 1 . the way buildings are orientated; 2 . the heat transmission through the roof; 3 . the use of high thermal mass building materials; 4 . the heat transmission through external walls and windows; 5 . the use of solar shading provided by outdoor and transition spaces.

\subsection{Orientation of the Buildings}

For the longer axis of a building, the best orientation in Curaçao is perpendicular to the East-West direction. This ensures that the majority of the walls and windows obtain the maximum input of daylight and airflow $[5,21]$. To minimize the negative effect of direct sunlight, the windows and the façades should be shaded, by e.g., overhangs, other types of shading or by vegetation as a shield to protect the façades and windows from the direct sunlight. The results reveal that the orientation of $83.5 \%$ of residential buildings and $81.7 \%$ of commerce buildings encourage both daylight and airflow.

\subsection{Heat Transmission through the Roof}

Fiber-reinforced roofing materials (eternit) is the most-used roofing material (73.3\%) of the investigated residential buildings, followed by zinc/aluminum $(12.7 \%)$, roof tiles $(5.7 \%)$, concrete $(3.2 \%)$, and shingles $(0.6 \%)$. About $4.5 \%$ of the examined residential buildings had a flat roof and it was not possible to identify the roofing. Figure 2 illustrates the roof materials used in the residential sector in Curaçao.

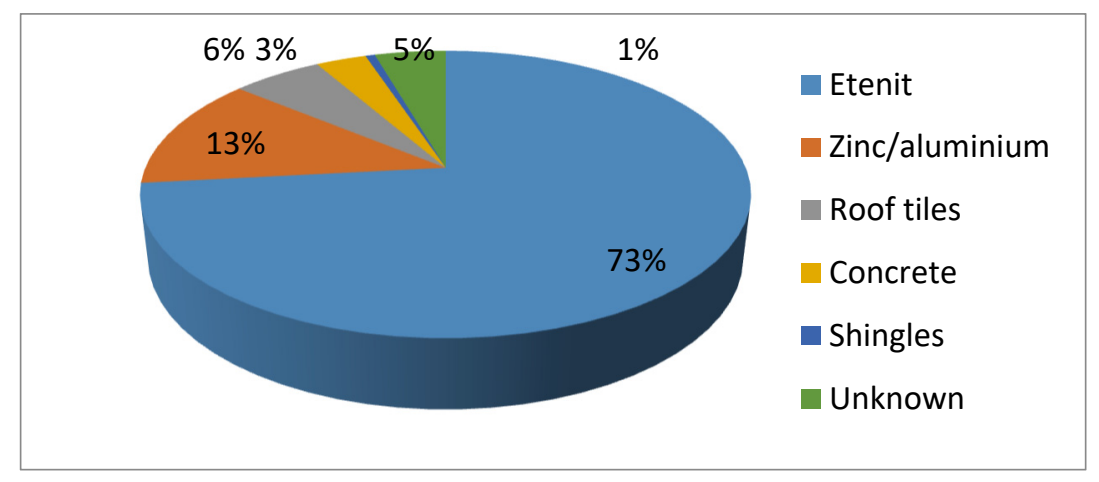

Figure 2. Roofing materials in the residential sector in Curaçao.

About $26 \%$ of the examined commercial buildings have fiber-reinforced roofing materials (Eternit), followed by roof tiles $(9 \%)$, shingles $(5.1 \%)$, and zinc/aluminum $(2.3 \%)$. The remaining $53 \%$ of the investigated commercial buildings had flat roofs of unknown material. Figure 3 presents the roof materials used in the commercial sector in Curaçao. It is likely that most of the flat roofs are made of concrete since this form of construction reduces the risks from storms and high winds. Another reason for including a concrete flat roof is that it makes it easier to expand the building in the future with one or more upper levels. A major disadvantage of these concrete roofs is that they often have a black bitumen layer which absorbs more heat than lighter colored roofs. Unfortunately, this study was not able to study the flat roofs to more definitely identify their construction. 


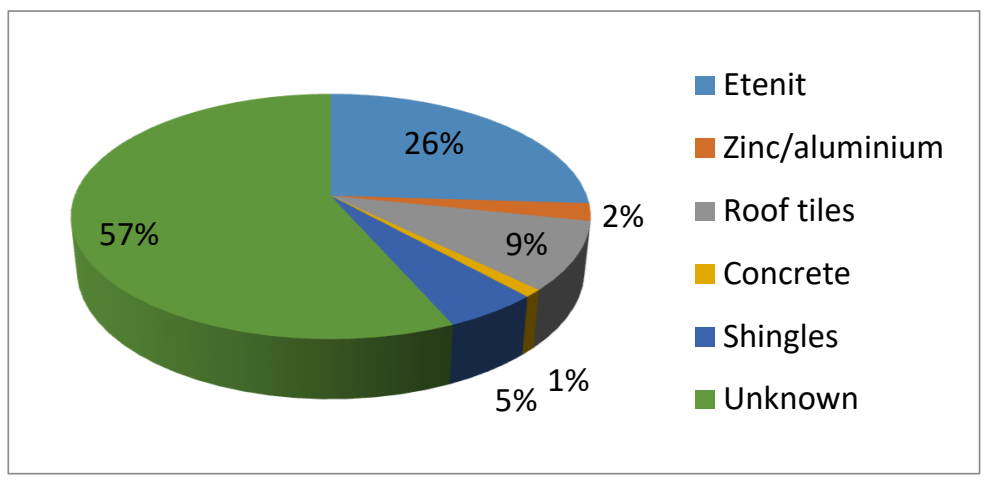

Figure 3. Roofing materials used in the commercial sector in Curaçao.

A notable observation is that due to a lack of maintenance, roofs can become discolored with a black layer due to pollution. As a consequence, the roof will absorb more heat, which will be transmitted to the interior of the building. This phenomenon was often observed during this investigation.

The results also show that approximately $42 \%$ of the roofs of the residential dwellings are lightly colored, while about $58 \%$ of the roofs have a dark color. The proportions are very similar in the commercial sector with around $41 \%$ of the roofs being a light color, and about $59 \%$ having a dark color. Here Google Earth was used to check the color of the flat roofs.

For the investigated residential and commercial buildings, about $62.9 \%$ and $31.6 \%$ respectively had some roof ventilation, however the roof ventilation of almost all the buildings was very limited. Only $22.9 \%$ of the investigated low-income residential buildings had roof ventilation.

\subsection{Thermal Mass Materials}

Almost all the buildings in Curaçao are built from concrete or cinder blocks (a hollow rectangular building block). About $98,7 \%$ of the examined commercial buildings are made of concrete or cinder blocks, while approximately $1.3 \%$ are constructed with timber or other materials (see Figure 4).

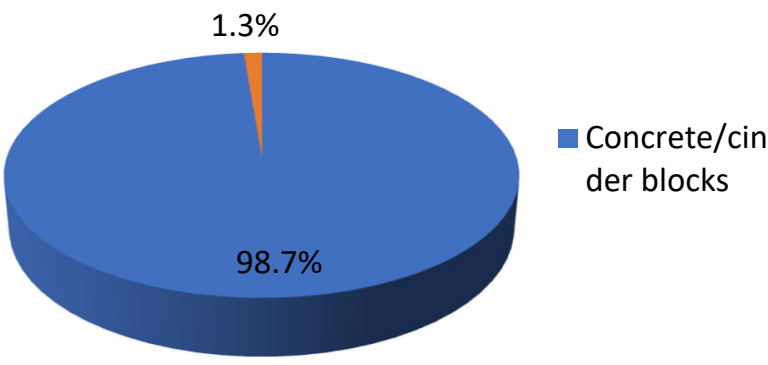

Figure 4. Building materials used in the commercial sector in Curaçao.

The results also indicate that roughly $97.1 \%$ of the investigated residential buildings are built from concrete or cinder blocks, while $1.9 \%$ of them are built of timber, and about $1 \%$ are constructed using both types of material (see Figure 5). It is important to note that all the examined residential buildings built of timber belong to low-income households. 


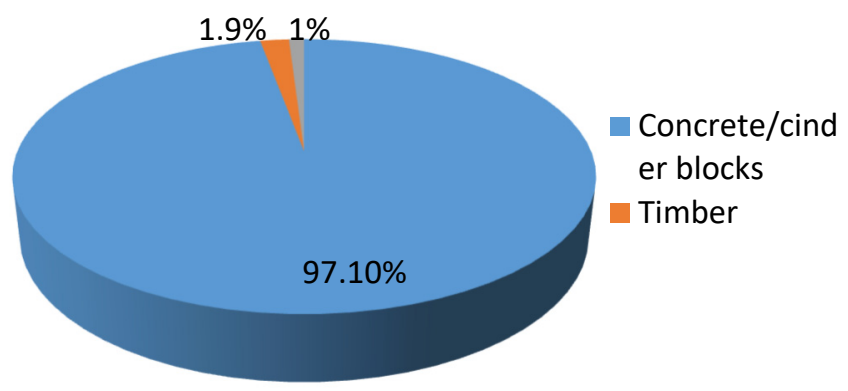

Figure 5. Building materials used in the residential sector in Curaçao.

\subsection{Heat Transmission through External Walls and Windows}

The study found that $61 \%$ of residential buildings have a light wall color, while $39 \%$ have a dark color. In the commercial sector, $46 \%$ of the commercial buildings have light colored walls while $54 \%$ of the commercial buildings the walls have a dark color.

Roughly $65.7 \%$ of the windows in residential buildings and $68.2 \%$ of those in commercial buildings are tinted glazed. However, only $9.5 \%$ of the low-income residential buildings have tinted glazed windows.

About $93.3 \%$ of the residential buildings have some form of solar shading, mostly in the form of overhanging elements. This is a higher proportion than with commercial buildings, where about $77.8 \%$ have a similar form of solar shading. It is important to note that, in most cases, the overhangs are small and therefore do not provide shade for the entire wall.

\subsection{Outdoor and Transition Spaces}

Almost all the investigated houses had at least one transition space or balcony (91\%), while $50.5 \%$ of the investigated commercial buildings had transition spaces. It is notable that only $23.5 \%$ of low-income residential buildings had transition spaces.

\subsection{Floor Levels}

Most of the buildings in Curaçao are single-story: approximately $84 \%$ of the residential buildings and about $72 \%$ of the commercial buildings have only one floor.

\subsection{Elevated Buildings}

In the field study, only two residential buildings were found in which a part of the building was elevated.

\subsection{Double Roof}

The study found that eight commercial buildings were found with a double roof.

\section{Discussion of Findings}

There are several passive cooling strategies to create a cooler building and to reduce energy use in tropical buildings. The key to designing a cooler building is to minimize heat gain and to harness natural ventilation. Based on the results of this study, the most important strategies which can be applied in Curaçao to create cooler buildings and through this to reduce energy use are summarized below. They are mirrored against the findings of the conducted field study.

\subsection{Use Low Thermal-Mass Building Materials to Reduce the Heat Gain}

Concrete or cinder blocks are commonly used in Curaçao. In case building materials with a high thermal mass, such as bricks and concrete, are used, it is essential to take compensatory measures. For example, the building façades need to be shaded to prevent heat gain and heat storage and the use of high thermal-mass materials in sleeping areas should be avoided or minimized. However, a preferred design strategy would be to use 
lightweight building materials such as timber. It is recommended to make an extensive study of potential alternative lightweight materials that can be used in the design and construction of houses and utility buildings.

5.2. Facilitate Natural Ventilation as Much as Possible in All Rooms of a Building through an Effective Layout Design

Natural ventilation was not investigated in the field study but should be promoted to reduce the use of air conditioners or other electromechanical systems.

5.3. Use Light Colors for Both the Walls and the Roofs of Buildings. Dark Colors Absorb Heat and Retain It Longer Than Light Colors

The field study shows that many buildings have dark colored roofs and also that there is a lack of maintenance to remove discoloration on roofs. The results of the field study also show that the residential sector in Curaçao is more aware of the effect of light colors on roofs and walls than the commercial sector. With respect to the use of windows and doors, it is recommended to promote the use of louvers for windows and doors and in case glass windows are considered essential, to use tinted glazed windows.

5.4. Shade the Buildings and Keep the Heat of the Sun Away from the Building. Overhangs, Sunshades, Trees, and Plants Are Good Options to Shade Buildings in Curaçao

Overhangs are widely used in Curaçao, but often do not have not the right size to completely shield the façade from the sun. It is recommended to design overhangs that obscure the entire wall.

5.5. Install Insulation in the Walls and the Roof of a Building. Insulation Reduces Heat Transfer through Walls and Ceilings and Also Reduces Heat Gain

The effect of Insulation in the walls and the roof of a building has not been investigated in the field study but should be promoted to reduce the heat transfer from outside the building.

5.6. Create Roof Spaces with Adequate Natural Ventilation. These Spaces Act as Buffer Zones and Reduce Heat Gain and Heat Transfer through the Building

Most of the investigated residential and commercial buildings, had some roof ventilation. However, the roof ventilation of almost all the buildings in the field study was very limited.

There are several passive design principles that can be applied in tropical regions to reduce energy use and improve thermal comfort. There are many people in Curaçao who are not aware of all these design principles. In Curaçao, people often only pay attention to the appearance of the building and the construction costs. In some cases, the building becomes more expensive if it is designed according to passive design principles. This is often one of the main barriers to adopting passive design principles. There must be regulations, motivational campaigns to implement the application of passive design principles and funds must be made available to help clients who are not financially strong build and/and renovate according to the passive design principles.

\section{Contributions, Recommendations and Limitations}

The first and main scientific contribution of this research is the development of a comprehensive overview of passive design principles that can be applied in the design and construction of buildings in tropical areas. This overview of passive design principles can be used by architects and contractors in tropical areas as a reference manual to design and build energy-efficient and comfortable buildings.

A second main scientific contribution is the identification of the extent to which passive design principles were adequately applied to 626 buildings on Curaçao. Based on the findings of this field study, the conclusion is justified that the use of high thermal-mass building materials, the dark color of many roofs, a lack of maintenance to remove black 
discoloration on roofs, and a lack of transition spaces in low-income dwellings, as well as in commercial buildings, all have a negative effect on the internal comfort and the potential to reduce the energy consumed by air conditioners. In addition, too few windows and doors appeared to facilitate natural ventilation and either did not protect against bright sunlight and consequently did not block heat absorption. This all has a negative effect on the internal comfort and the potential to reduce the energy consumed by air conditioners. Moreover, although most of the walls have solar shading, in most cases this shading is too small and insufficient to shade the entire wall of the building. This insufficiency is also the case with respect to roof ventilation: although several dwellings are designed with roof ventilation, the ventilation openings are often too small to make a real difference.

The research findings show an insufficient application of the passive building design principles on Curaçao. This may be caused by a lack of awareness among architects, contractors and building owners on the island of the potential benefits these principles. Promoting the benefits of energy-saving and increased comfort, may hopefully result in a greater awareness among all the stakeholders to adopt passive building design principles. To this end it is recommended to setting up and organizing targeted awareness campaigns on adopting passive building design principles.

The adoption of applying passive building principles will also benefit highly if supported by the government. To this end it is recommended to introduce passive building energy codes in which the application of passive building design principles is described as mandatory.

Curaçao has been taken as a case example to study the application of passive building design principles in practice. Unfortunately, we do not expect that the results will differ considerably in other tropical regions. However, additional research is needed to determine to what extent this expectation maybe correct. Another limitation of this study is that due to the methodology that was followed, not all passive building design principles could be evaluated. Additional research is also needed here to verify the awareness and application of these passive building design principles.

Author Contributions: R.B. performed the conducted field study and also the field data analysis. When conceptualizing and writing the paper, both authors equally contributed. All authors have read and agreed to the published version of the manuscript.

Funding: This research received no external funding.

Institutional Review Board Statement: Not applicable.

Informed Consent Statement: Not applicable.

Data Availability Statement: Data are available on request by contacting the corresponding author.

Conflicts of Interest: The authors declare no conflict of interest.

\section{References}

1. Aflaki, A.; Mahyuddin, N.; Mahmoud, Z.A.; Baharum, M.R. A review on natural ventilation applications through building façade components and ventilation openings in tropical climates. Energy Build. 2015, 101, 153-162. [CrossRef]

2. Cairns Regional Council. Sustainable tropical building design: Guidlines for commercial buildings. Wetlands 2011, 48. Available online: http:/ / www.cairns.qld.gov.au/_data/assets/pdf_file/0003/45642/BuildingDesign.pdf (accessed on 1 June 2021).

3. Chenvidyakarn, T. Review article: Passive design for thermal comfort in hot humid climates. J. Archit. Plan. Res. Stud. 2007, 5, 5-27.

4. Rodriguez-Ubinas, E.; Montero, C.; Porteros, M.; Vega, S.; Navarro, I.; Castillo-Cagigal, M.; Matallanas, E.; Gutiérrez, A. Passive design strategies and performance of Net Energy Plus Houses. Energy Build. 2014, 83, 10-22. [CrossRef]

5. Brown, L.; Eman, R.; Halman, J.; Lauffer, E. Bouwfysisch Verantwoord Bouwen op Curacao; TU Delft: Delft, The Netherlands, 1974.

6. Tantasavasdi, C.; Srebric, J.; Chen, Q. Natural ventilation design for houses in Thailand. Energy Build. 2001, 33, 815-824. [CrossRef]

7. Kitio, V.; Butera, F.M.; Adhikari, R.; Aste, N. Sustainable Building Principles and Applications for Eastern Africa; United Nations Human Settlements Programme (UN-Habitat): Nairobi, Kenya, 2014; 427p.

8. Jamaludin, N.; Khamidi, M.F.; Abdul Wahab, S.N.; Klufallah, M.M.A. Indoor thermal environment in tropical climate residential building. In Proceedings of the Emerging Technology for Sustainable Development Congress (ETSDC 2014), Bangi, Malaysia, 5 August 2014. [CrossRef] 
9. Organization of American States. Department of Sustainable Development. Energy Efficiency Guidelines for Office Buildings in Tropical Climate. 2013. 186p. Available online: http://www.oas.org/en/sedi/dsd/energy/doc/8a._energy_efficiency_ guidelines_for_office_buildings.pdf (accessed on 1 June 2021).

10. Liu, F.; Meyer, A.; Hogan, J. Mainstreaming Building Energy Efficiency Codes in Developing Countries: Global Experiences and Lessons from Early Adopters, First; World Bank: Washington, DC, USA, 2010.

11. Wong, N.H.; Feriadi, H.; Lim, P.Y.; Tham, K.W.; Sekhar, C.; Cheong, K.W. Thermal comfort evaluation of naturally ventilated public housing in Singapore. Build. Environ. 2002, 37, 1267-1277. [CrossRef]

12. Bastide, A.; Lauret, P.; Garde, F.; Boyer, H. Building energy efficiency and thermal comfort in tropical climates. Presentation of a numerical approach for predicting the percentage of well-ventilated living spaces in buildings using natural ventilation. Energy Build. 2006, 38, 1093-1103. [CrossRef]

13. Prianto, E.; Depecker, P. Optimization of architectural design elements in tropical humid region with thermal comfort approach. Energy Build. 2003, 35, 273-280. [CrossRef]

14. Reardon, C.; Clarke, D. Passive Cooling. 2013. Available online: https://www.yourhome.gov.au/passive-design/passive-cooling (accessed on 1 June 2021).

15. Diaz, C.H. Advice from an Architect: 10 Tips to Create a Cooler Home. 2016. Available online: https://www.rappler.com/lifeand-style/arts-and-culture/122067-advice-architect-tips-cooler-home (accessed on 11 December 2018).

16. Khedari, J.; Boonsri, B.; Hirunlabh, J. Ventilation impact of a solar chimney on indoor temperature fluctuation and air change rate in school building. Energy Build. 2000, 32, 89-93. [CrossRef]

17. Mallick, F.H. Thermal comfort and building design in the tropical climates. Energy Build. 1996, 23, 161-167. [CrossRef]

18. Rattanongphisat, W.; Rordprapat, W. Strategy for energy efficient buildings in tropical climate. Energy Procedia 2014, 52, 10-17. [CrossRef]

19. Latha, P.K.; Darshana, Y.; Venugopal, V. Role of building material in thermal comfort in tropical climates-A review. J. Build. Eng. 2015, 3, 104-113. [CrossRef]

20. Feriadi, H.; Wong, N.H. Thermal comfort for naturally ventilated houses in Indonesia. Energy Build. 2004, 36, 614-626. [CrossRef]

21. Bulbaai, R. Toward 100\% Sustainable Energy Production and a Structural Decrease in Energy Demand: Curacao, as a Case Study of Small Island Developing States. Ph.D. Thesis, University of Twente, Enschede, The Netherlands, 2019.

22. Central Bureau of Statistics Curacao. Available online: www.cbs.cw (accessed on 8 December 2015).

23. Meteorological Department Curacao. Climatological Summary; Meteorological Department Curacao: Willemstad, Curacao, 2018.

24. CBS. Leegstaand op Curacao; Een onderzoek naar de ontwikkeling van de woningleegstand tussen 2011 en 2017 ; Central Bureau of Statistics: Willemstad, Curacao, 2019; 56p. Available online: http:/ / digitallibrary.cbs.cw/cbs0000482/00001 (accessed on 1 June 2021).

25. Alamy Curacao Road Vector Map. Available online: https:/ /www.alamy.com/stock-image-curacao-road-vector-map-168319707. html (accessed on 25 October 2021). 